\title{
JAWABAN SOAL UTS 2018/2019 MATAKULIAH PRAKTEK PEMOGRAMAN BORLAND DELPHI
}

SUHARYANTO

165100070

Fakultas Komputer, 448757230

randisaputra.student@institusi.ac.id

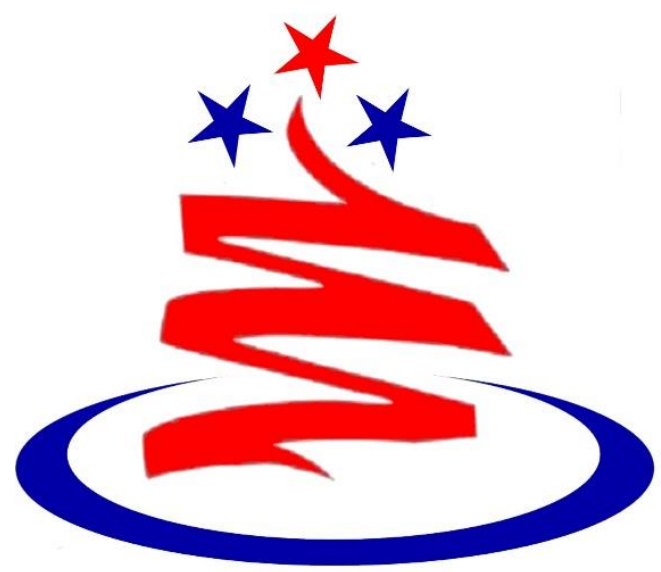

UnIVERSITAS mITRA InDONESIA 


\section{A. STUDI KASUS ( SK )}

Pertanyaan Type B :

Paparkan dan jelaskan logo anda

Jawaban:

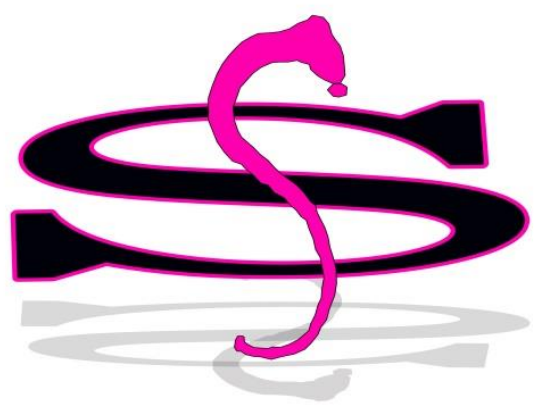

Logo ini adalah logo keluarga saya sendiri, karna selmua keluarga saya berinisial "S" di logo tersebut $\mathrm{S}$ hitam melambangkan konsisten,tegas,dan bertanggung jawab melambangkan sebuah pemimpin seperti ayah saya. "S" merah muda melambangkan kelembutan kasih sayang seperti ibu. 


\section{B. STUDI REFERENSI ( SP )}

Pertanyaan Jenis A :

Jelaskan fungsi-fungsi detail dalam objek inspector

Jawaban : Tujuan Inspeksi (Inspection) dalam Pengendalian Kualitas

Tujuan dari Inspeksi dalam Quality Control (Pengendalian Kualitas) adalah sebagai berikut :

1. Untuk mendeteksi dan menghilangkan bahan baku yang cacat sebelum masuk ke proses produksi.

2. Untuk mendeteksi produk cacat dan produk yang berkualitas rendah terkirim ke pelanggan.

3. Untuk memberikan pemberitahuan kepada Manajemen sebelum suatu masalah kualitas menjadi serius sehingga manajemen dapat mengambil tindakantindakan yang diperlukan.

4. Untuk mencegah keterlambatan pengiriman yang dikarenakan masalah kualitas dan mengurangi keluhan dari pelanggan.

5. Untuk meningkatkan kualitas dan realibilitas produk.

\section{Manfaat Inspeksi (Inspection) dalam Pengendalian Kualitas}

1. Membedakan Lot produk yang baik dan Lot produk yang cacat.

2. Membedakan unit produk yang baik dan unit produk yang cacat.

3. Untuk mengetahui apakah terjadi perubahan pada proses.

4. Untuk mengetahui apakah proses produksi berada atau mendekati batas spesifikasi.

5. Untuk menilai kualitas produk.

6. Untuk mengukur ketepatan alat ukur di produksi.

7. Untuk mengukur kemampuan proses.

8. Jenis-jenis Inspeksi dalam Pengendalian Kualitas 


\section{STUDI PENALARAN ( SP )}

Pertanyaan Kategori 2 :

Buatlah aplikasi segitiga

Jawaban :

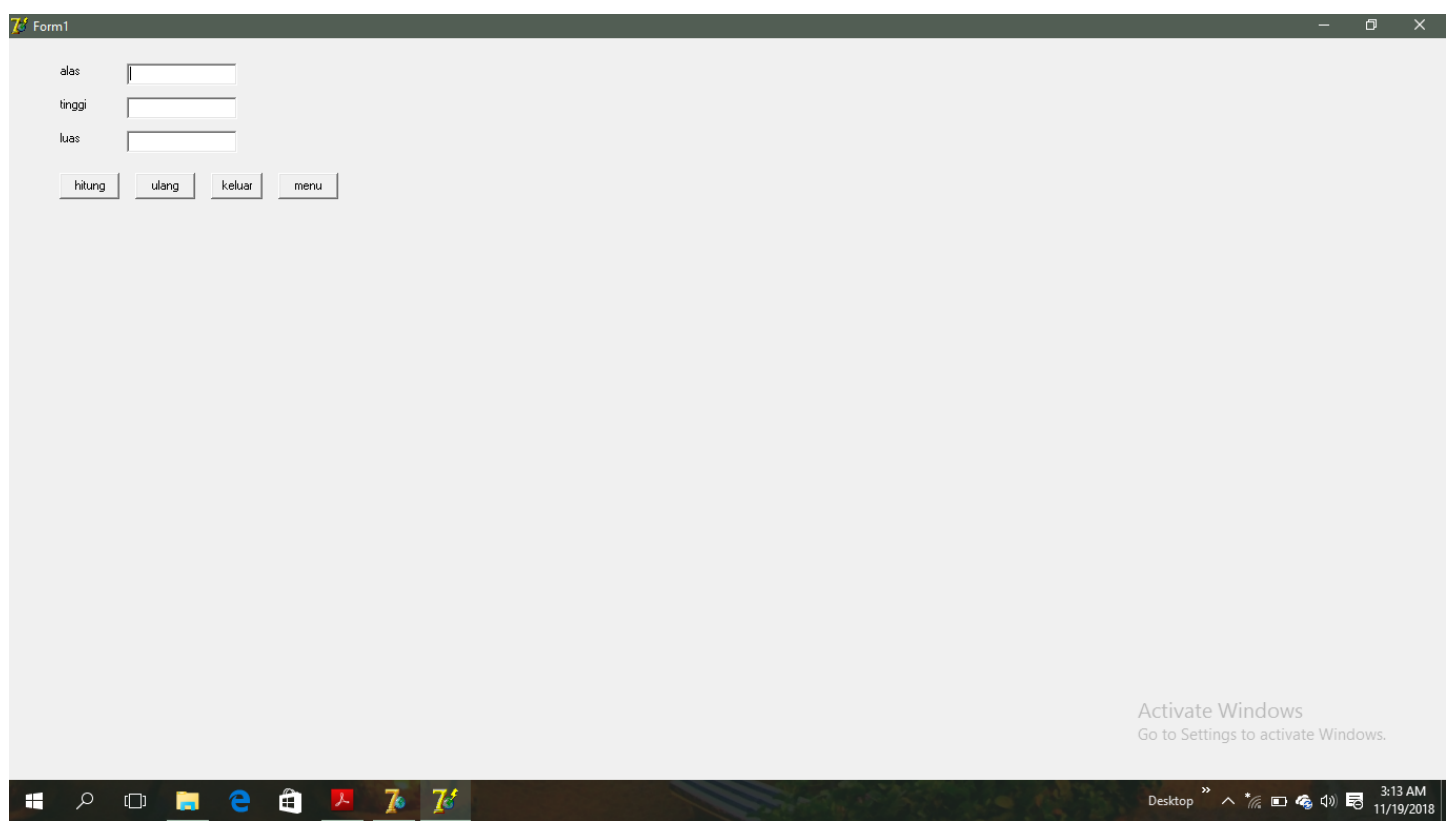




\section{REFERENSI}

[1] A. S. Putra And O. M. Febriani, "Knowledge Management Online Application In Pdam Lampung Province," In Prosiding International Conference On Information Technology And Business (Icitb), 2018, Pp. 181-187.

[2] A. S. Putra, O. M. Febriani, And B. Bachry, "Implementasi Genetic Fuzzy System Untuk Mengidentifikasi Hasil Curian Kendaraan Bermotor Di Polda Lampung," J. Sist. Inf. Dan Manaj. Basis Data, Vol. 1, No. 1, Pp. 21-30, 2018.

[3] O. M. Febriani And A. S. Putra, "Sistem Informasi Monitoring Inventori Barang Pada Balai Riset Standardisasi Industri Bandar Lampung," J. Inform., Vol. 13, No. 1, Pp. 90-98, 2014.

[4] Putra, Arie Setya. "2018 Artikel Struktur Data, Audit Dan Jaringan Komputer." (2018).

[5] Putra, A. S. (2018, July 17). Paperplain Fundamental Create Application With Borland Delphi 7.0 University Of Mitra Indonesia. Retrieved From Osf.Io/Pbrn9. 